Artículos

\title{
MEDIA EVENTS AND GEO-CULTURAL MARKETS: NARRATION AND FRAMING OF THE 2010 CHILEAN MINING ACCIDENT IN NEWSPAPERS IN CHILE, MEXICO, AND SPAIN
}

\author{
Christian Morgner \\ University of Leicester, Reino Unido \\ Francesca R. Molina \\ University of Leicester, Reino Unido \\ Autor para correspondencia: Christian Morgner, e-mail: cm570@1e.ac.uk
}

\begin{abstract}
This study examines media events from the perspective of geo-cultural markets by analyzing the media frames utilized during print media coverage of the Chilean mining disaster of 2010 in newspapers from Chile, Mexico, and Spain. The paper assesses the narratives, dynamics, and perspectives in two main frames -love and heroes- to further our understanding of framing strategies in the Hispanic geocultural market by addressing how geo-cultural markets can reinforce, localize or transcend frameworks or differ internally. The aim is to problematize the apparent standardization of geo-cultural markets and to analyze its differential occurrence in framing, identifying correlations and dissimilarities among representations of the mining accident in the three nations. Also, the research highlights the variables within each frame and their association with the cultural features of the Global South, rendering the concept of framing more adaptable and flexible. Finally, the paper demonstrates that frames of affection and emotion were highly influential in turning the Chilean mining disaster into a media event.
\end{abstract}

Keywords: media events, framing, emotion, transnational

\section{Resumen}

Este estudio examina los eventos mediáticos desde la perspectiva de mercados geo-culturales al analizar los encuadres mediáticos utilizados durante la cobertura de los medios impresos del desastre minero chileno de 2010 en periódicos de Chile, México y España. El estudio evalúa las narrativas, dinámicas y perspectivas en dos encuadres principales -amor y héroes-para profundizar nuestro entendimiento de las estrategias de encuadre en el mercado geo-cultural hispano al abordar cómo los mercados geo-culturales pueden reforzar, localizar o trascender los marcos de referencia o diferir internamente. El objetivo es problematizar la aparente estandarización de mercados geo-culturales y analizar su ocurrencia diferencial en los encuadres, identificando correlaciones y disimilitudes entre las representaciones del accidente minero en las tres naciones. Además, la investigación destaca las 
variables en cada encuadre y su asociación con las características culturales del Sur Global, haciendo del concepto de encuadre uno más adaptable y flexible. Finalmente, el estudio demuestra que los encuadres de afecto y emoción fueron altamente influyentes para convertir al desastre minero chileno en un evento mediático.

Palabras clave: eventos mediáticos, encuadre, emoción, transnacional

Recibido: $27 / 08 / 2018$

Aceptado: 09/01/2019

\section{Introduction}

There is growing research interest in media events (Fox, 2016), including studies of major sporting events, catastrophes, terrorist attacks, royal weddings, presidential inaugurations, and televised debates. However, most of this research deals with events occurring in the Western hemisphere or focuses on the coverage in Western media. For instance, the well-known publication by Dayan and Katz (1992) principally addresses the wedding of Princess Diana and the assassination of John F. Kennedy; the only non-Western event in the book concerns the peace negotiation between Egypt and Israel but remains focused on media coverage in the U.S.

There is also a tendency to discuss media events that occur in the Global South from a local versus global perspective. These studies tend to highlight drastic or exotic differences between media coverage in the West and other parts of the world. One relevant example is Jiménez-Martínez's (2014) examination of the Chilean mining accident, which explored the media narrative constructed by a national television news provider as compared to a global broadcaster. While offering valuable insights at national and global levels, Jiménez-Martínez's analysis overlooked an important issue: that beyond any underlying notion of Chile as differing from the rest of the world, these seemingly different narratives might be a typical outcome of journalistic practice, in which frameworks tend to be localized and embedded in a region's existing mediascape. The present study addresses the transnational dimension of media events from the perspective of geo-cultural markets (Straubhaar, 1991, 1997, 2007), which suggests that certain regions share a common history, language, and cultural orientation, shaping how an event is likely to be received.

In particular, we focus here on the catastrophe in Chile in 2010, when the San José gold-copper mine in northern Chile's Atacama Desert collapsed, trapping 33 miners 700 meters underground. More than two weeks later, a note was recovered, stating that the men had found shelter and were alive. Research on important media events has mostly overlooked this catastrophe, which involved transnational elements within a particular Hispanic geo- 
cultural market and therefore seems worthy of investigation. When the accident happened in 2010 , it could not have been predicted that the event would attract such widespread news coverage around the globe, not only in newspapers in the Hispanic world but also in North America, Europe, Australasia and even in Asia. Our focus is on the geo-cultural market facilitates more fine-grained analysis of cultural and linguistic differences in media coverage, without the risk of overestimating such differences because they occur in seemingly diverse cultural markets. The following questions drive the research:

1. How was the media event framed within its geo-cultural market (the Hispanic world)?

2. What were the differences and similarities in the reporting of this event in this market?

3. How did this accident become a media event?

\section{Frame Analysis and Framing Disasters}

Throughout its development, framing analysis has become a reliable tool as part of a theoretical approach to communication studies, social movements and related policy studies (D’Angelo \& Kuypers, 2010). In its beginnings, Goffman (1974) suggested that individuals "Have the capacity and inclination to use concrete, actual activities - which are meaningful in their own right - as a model upon which to work transformations for fun, deception, experiment, rehearsal, dream, fantasy, ritual, demonstration, analysis, and charity" (p. 560).

Frames in communications serve as the organizers, constructors and defining structures of the ideas of a message: "Framing is the process by which a communication source, such as a news organization, defines and constructs a political issue or public controversy" (Nelson, Clawson \& Oxley, 1997, p. 221). It is, therefore, possible to say that frame analysis functions as an instrument to observe how people decode certain messages. Bullock, Wyche, and Williams (2001) suggests that framing is a powerful resource formed by typically unnoticed devices affecting the public's judgments of responsibilities and causes. Moreover, in order to validate and be able to use a frame as a reliable reference point, researchers have argued that frames ought to have identifiable concepts and linguistic features that can extend frame analysis into discourse and semiotic analysis (e.g., Lozano, Abril, Peña-Marín, 1993; Lozano, Peña-Marín, Abril, 2004; Hansen \& Machin, 2018). Van Gorp (2007) maintained that a variety of elements play a role in framing analysis, such as reasoning devices, framing devices, frame packages, and graphic representations. Frame packaging consists of social meaning-making strategies and how they are logically organized. They are shaped by framing devices such as language (word choice, similes, statements, descriptive language, and visual images) and reasoning devices (causes, consequences and justifying comments). 
Frames are a central part of a culture. Culture in itself can have a defining role in structuring a particular frame. Depending on the perseverance of the frame, people's views and perceptions may be influenced. According to Entman (1993), the cultural background of a society is a determining factor in the reception of different frames. In other words, frames rely on the cultural aspects of a community to function, and subsequently, it is possible to say that frames flow and expand their branches continuously throughout geo-cultural markets.

Most of the full range of definitions of disaster (Perry, 2007) seem to emphasize a physical impact on a human system that is unplanned, surprising or accidental. Disaster prevention, therefore, tends to focus on creating reinforced and more durable forms of infrastructure and shelter or protection. Similarly, disaster management emphasizes technical and logistical support for the communities affected by a tornado, earthquake or flood. Under their accidental occurrence and the physical damage and disruption they cause to human systems, mining accidents are seen as disasters. However, this quite technical conception seems too general to make sense of the case discussed here. The San José Mine has a long history. Founded in 1889, it is located 45 kilometers northwest of Copiapó. Although it had previously seen many fatal accidents and had been closed at various times, none of these closures became a media event. The first question, then, is why the mining accident discussed here was different. The suggested answer is that the usual frames, which highlight a disaster's technical or natural dimension, were replaced by a media event frame that focused on two aspects of emotional disruption: love and heroes. The research suggests that these frames were supported by being embedded in a specific geo-cultural market. While the love frame can be seen to signify a personal or family-like relationship between like-minded people, the hero frame has a transcending quality, uniting people from Latin America in their struggle against such forms of adversity as political suppression, corruption, and poor leadership.

\section{Methodology and Data Collection}

To address the research questions, frame theory was considered the most appropriate approach, encompassing word selection, descriptions, arguments, metaphors, images and captions and enclosing a wider range of events, including disasters (Entman, 1991). As stated by Reese, Gandy, and Grant (2008), within framing analysis, frame theory engages more than content or discourse analysis with the cultural setting. According to Janssen (2010, p. 24), "reasoning devices are explicit and implicit statements that deal with justifications, causes, and consequences." This is relevant here, as the Chilean mining accident was a local event that reached beyond geographical and cultural boundaries in attracting global attention. With this in mind, the present investigation sought to establish whether the differences in framings across publications could be described in quantitative as well as qualitative terms. The 
framing disaster approach enabled us to explore the components of the transnational element of the event as part of the local news within each of the other two countries (Mexico and Spain) representing the Hispanic geo-cultural market. The approach comprehends similarities and differences in the messages delivered in the three countries, as well as analyzing the distinctive meanings, contexts and underlying agendas communicated by these newspapers.

For this research, three national newspapers (one from each country) were chosen: Las Últimas Noticias from Chile, $L a$ Jornada from Mexico and El País from Spain, all of which covered the mining event throughout two and a half months. These publications were selected because of their national readership and circulation, and because they present varied journalistic perspectives; for instance, El País is slightly conservative and La Jornada more liberal. The publications were reviewed for the period from the occurrence of the accident in August, 2010 through September and October, of that year.

To facilitate a comparable qualitative analysis, a collection of news reports was gathered for each of the sixty-nine days (August $5^{\text {th }}, 2010$-October $13^{\text {th }}, 2010$ ) on which the event was reported, and all stories (more than a hundred articles) from each newspaper were read. All newspapers were available in print. The analysis focused on the specific dates on which the event gained prominence: the beginning (initial media coverage of the collapse of the mine); the development (thirtythree miners found alive); the climax (digging machinery getting closer to the men); and the conclusion (the rescue and the miners' return to the surface). This strategy was adopted because, during the process of reporting the mining accident, some items were either summary of the previous days or intertwined other news events with coverage of the miners (such as the political protests reported during one week in Las Últimas Noticias). Additionally, no relevant articles appeared on certain dates in $L a$ Jornada and El País. All quotes presented here were translated from the Spanish original and further reviewed by the relevant researcher to maintain the language's accuracy and to preserve its intended meaning.

\section{Findings}

\section{The Love Frame: Emotional Disruption and the Formation of Relationships}

The analysis of media coverage across the three selected newspapers revealed a shared 'love frame,' which they developed similarly throughout the event regarding language, quotes, and selection of stories. This can be seen to make sense within the idea of a Hispanic geo-cultural market, as Chile, Mexico, and Spain share that historical and cultural background. The analysis found that the main difference between these countries was in the timing, intensity and quantity of usage of this frame, which seems to vary at different stages: before and after the miners were found alive, and in the periods before and following their rescue. The frame's development followed 
three stages. In the initial stage, there was a more local focus, notably in Chile's Las Últimas Noticias $(L U N)$. This frame created a priming effect that was subsequently picked up by the Mexican newspaper La Jornada and the Spanish El País as an extended and developed love frame. During the third stage, El País and $L U N$ reported romantic love stories between the miners and their partners to a similar extent. In La Jornada, this type of narrative was less evident, providing scope for new frames that would extend the narrative, creating a networklike structure (Morgner, 2016). We propose that the love frame offered a new perspective on disasters and effectively served as a narrative guide, stimulating subsequent frames developed in other regions. However, once the frame was established, it created an event powerful enough to reinvent and maintain itself through the creation and interlinking of new frames.

\section{Love Frame, First Stage: Agape}

In itself, love can be considered a diverse concept, which has been argued to include complex metaphorical conceptions. The ancient Greeks described agape love as 'charitable love' (Liddell \& Scott, 2010). Subsequently, the term's meaning extended to a love that is reciprocal among humans (Hoiberg, 2010). Martinovsky (2010) has suggested that the empathic emotions found in discursive and linguistic features lead to social behaviours that are emotive in nature. This occurs by a process of association in which existing experiences already carry certain meaning; when they encounter similar representations, whether in the form of words, symbols, visual images or sounds, they connect, and these original experiences are revisited or relived. The use of emotive language in dealing with a catastrophic event seems to appeal to human empathic emotions, and the media framing of this narrative into defined love frames can therefore reach a wider audience.

In the early coverage of this event, the first stage Agape love frame appeared almost naturally in Chile as the accident location. In $L U N$, this emotive language recurred in the headlines and sub-headlines of most early reports, which tended to focus on rescue efforts and the uncertainty of finding the 33 miners alive. Family members and rescue workers gathered around the mine were quoted repeatedly; in $L U N$, the selected quotes often contained such words or phrases as hope, sadness, lost, desperation, crying, reunited, despair, distress, being strong, resilience, anguish, unbearable, pain and waiting, accompanied by use of the conditional tense in verbs such as could, should, may and might, and wording like it is possible, unknown, difficult, yet. 
Table 1: Love Frame: First Stage

\section{Source: $L U N$}

"The agonising hours of 34 men trapped in the centre of a mountain" (August $7^{\text {th }}, 2010$, front cover headline).

"Small shelter is the only hope for 33 men" (August $7^{\text {th }}, 2010$, front cover).

"Inconsolably crying families after hearing of possible failure of rescue efforts of their loved ones" (August $8^{\text {th }}, 2010$, p. 2).

"At hour 14, there was despair [...] first it was a whisper, then a piercing sound of tears and crying in the saddest moment of all" (August 13 ${ }^{\text {th }}, 2010$, p. 4).

"Rescue worker: when I saw the rock, I felt I was going to $c r y . .$. I felt so sad looking at everyone around me [...] they were hopeful and now it seems more difficult to find them alive, it hurts" (August $17^{\text {th }}, 2010$, p. 3).

“Anguish amongst miner's families as time is running out" (August $20^{\text {th }}, 2010$, p. 8).

This lexicon (Table 1) tends to be used in the initial stages of reporting and framing disasters. It can be found in reports of earthquakes, hurricanes and natural events in which estimates of death and damage use conditional language, as factual information takes time to appear. The choice of language reflects a more general type of love framing: humans feeling compassion and sympathy for other humans.

Figure 1. Building Relationships and Emotive Reactions
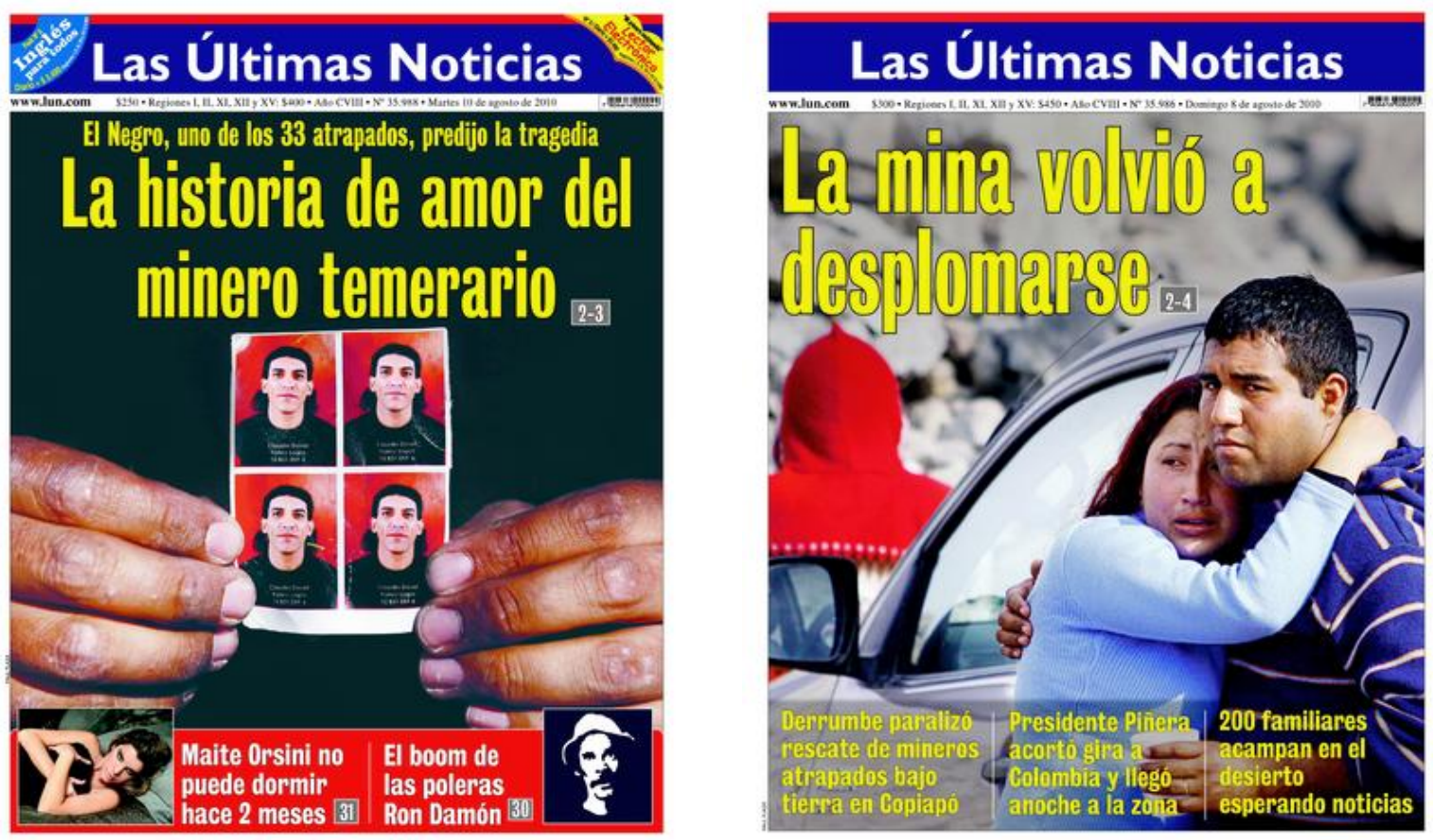

Source: LUN August 10 $0^{\text {th }}, 2010$ (front cover) and LUN August $8^{\text {th }}, 2010$ (front cover). 
In another example, from August $8^{\text {th }}, 2010$, $L U N$ 's main front cover headline highlights the "desperation of the families, who crying and holding each other, despair about this tragedy" (see Figure 1). The image portrays a man and a woman in visible distress; she is crying, and he appears to be consoling her with an embrace. A further three full pages are dedicated to news of the mining accident. On August 12 ${ }^{\text {th }}, 2010$, according to $L U N$ (p. 6), "The day a policeman cried together with the miner's families," followed by a caption and a subheading: "The tough sergeant could not contain his emotions." The language aligned with an emotive narrative concerning the improbability of finding the 33 miners alive. Again, it seemed to appeal to the audience's empathic emotions in relation to loss, uncertainty and closure.

Framing analysis suggests that not all frames are of equal status (Levin, Schneider \& Gaeth, 1998). In particular, frames that emerge early may have a decisive quality that prime the development of meta-frames into which subsequent media reports can be integrated, which seem to regulate overall narration of the event (Iyengar \& Simon, 1993; Brewer, Graf, \& Willnat, 2003; Schultz, Kleinnijenhuis, Oegema, Utz, \& Van Atteveldt, 2012). As will be demonstrated in the next section, this first frame was reinforced through embedding into a transnational (i.e. Latin-American) context of shared feelings and so had a crucial effect on media coverage in other countries. As international newspapers initially had limited access to the event, they depended on media coverage originating in Chile.

\section{Love Frame, Second Stage: Pragma and Storge}

Storge and pragma love are linked through shared meanings. Hooper (2005) characterized these definitions of love in terms of "strong affections between family members, friends, companions and underpin exceptional desires to care compassionately for one another." Pragma has been defined as love that develops between a couple over time by working on the relationship and showing patience and tolerance (Krznaric, 2014). In the second stage, the stories selected by the three newspapers contained references and written material quoting the miners' family members, relatives and friends. In their consistent use of emotive language, the linguistic repertoire of these interviewees appeared in keeping with the seriousness of the event. As mentioned previously, this part of the frame gained prominence after the miners showed signs of being safe in the refuge. The first contact between the miners and their relatives was through an exchange of letters; subsequently, the miners were given cameras to record messages. While most of this material was kept private, some videos were broadcast exclusively by the Chilean news before being passed on to other providers, and reporters used interviews with relatives to gather information for publication. 


\section{Table 2: Love Frame: Second stage}

\section{Source: $L U N$}

"Miner took the opportunity to say he loves his wife" (August 23th, 2010, p. 3).

"We are very happy—greetings to my wife, children and friends" (September $1^{\text {st }}, 2010$, p. 3).

\section{Source: El País}

"...this is equivalent to the birth of a son, said an emotional rescue worker" (23 August 2010, International p. 3).

"In all (Chilean) homes, tears of happiness and joy were found" (August $26^{\text {th }}, 2010$, International, $p$. 4).

\section{Source: La Jornada}

"Families had the chance to speak on the phone (with miners); those were moments of great joy" (August 30 ${ }^{\text {th }}, 2010$, World, p. 31).

Quotes containing the miners' views and perceptions and their interactions with relatives and friends constituted an important part of the pragma love frame in this second stage of reporting. Most of the articles printed daily in $L U N$ and El Pais (and fairly regularly in $L a$ Jornada) included selected quotes relating people's perceptions and views as soon as there was any development (Table 2). Personal stories and insights into the lives of the miners, as well as the whereabouts of family members, were highlighted on most days. As in $L U N, E l$ País and La Jornada included quotes from the miners' wives in their reports, expressing their concerns and "hoping to be reunited as soon as possible" with the men. The love frame was embedded in a wider network of media messages, using this personalized approach to capture the significance of the incident. In this way, the event established a shared sense of individual experience in the public sphere. In other words, the emphasis on individual relationships established a point of reference that extends beyond any differences by which we identify ourselves and those around us. Within the framework of the media event, this has the effect of creating the impression of actual directness, of a participating intimacy or "a kind of immediate personal involvement" (Ong, 2002, p. 502).

Reports in $L U N$ contained numerous individual and collective stories about the relatives and family-related issues. In these reports, each miner and their relatives were referred by name and surname. Abandoning the anonymity of the first stage, the connection with the audience now became closer, as the reader was presented with a more open cognitive concept. The pragma and storge love frame features more mixing up generic with personified emotional language, as in LUN's August $17^{\text {th }}, 2010$ edition: "María, José Ojeda's wife, sits down and inconsolably cries she manages to speak: 'I want to be sure they are okay, it is all very hard'." In this second and last remaining stage, proper names were also used 
in quotes in La Jornada and El País. In this way, the personal element was supported by a feeling of belonging and relationship within a cultural sphere that seems to share these feelings and a common understanding of the situation. It was here that further connections started to develop between the countries, as interest and access to the event grew. For instance, on August $23^{\text {rd }}$, El País printed a quote from one of the wives, who read part of a letter: "give many kisses to my children and grandchildren [tell them] I love them, [tell them] to be calm. For you, my biggest love, I love you so much. We will be happy forever together with our family; we will see each other soon, bye my darling, I love you" (El País, 2010).
This was followed by a description of the miner who wrote the letter as a cheerful and stoic man, along with the names and age of his partner. Details of relationships were commonly given, including how long a couple had been married and other family information. In the same way, La Jornada used quotes that aligned with the pragma love framing-for example, a miner's wife was quoted as saying "I am going to wait as long as needed to see my husband again-Lilianet Ramirez." In another example, a miner's cousin said "hope was never lost, we just have to wait a little longerArnoldo Plaza" (La Jornada, August $23^{\text {rd }}$, 2010, p 2).

Figure 2. Emotive Expressions

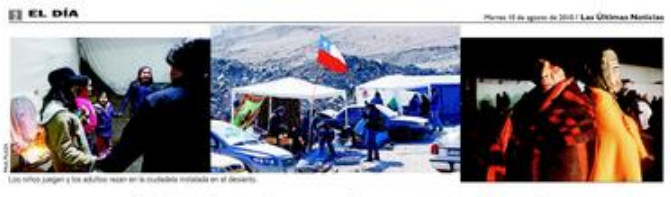

La historia de amor del minero que predijo la tragedia

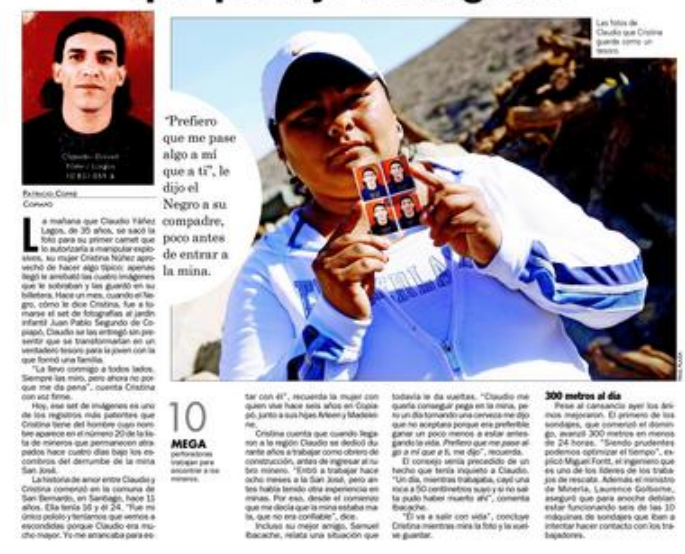

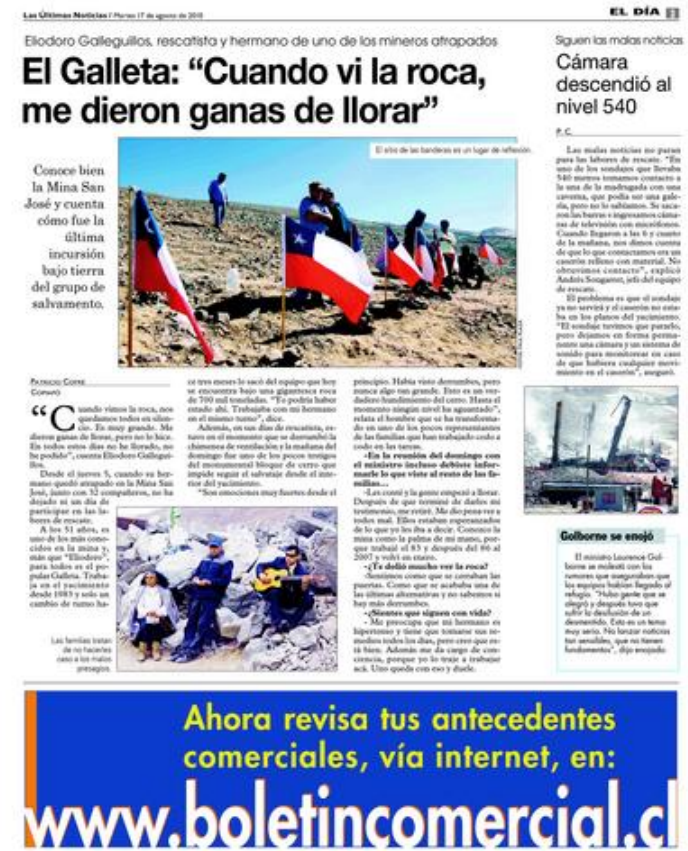

Source: $L U N$ August $10^{\text {th }}, 2010$, p. 2; $L U N$ August 17 $7^{\text {th }}, 2010$, p. 10. 
Pictures of the families' improvised camp around the mine were also used regularly in support of this frame, with close-ups of people's faces, highlighting their expression. Captions frequently contained words, phrases, similes and metaphors such as hope, joy, care, kisses, reunited, children, listening to voice of loved ones, long wait, awaiting hugs, worry and distance. Again, this narrative produced emotions in the reader that might appeal to human empathy, fetishism or either, instilling curiosity or a desire to know more. As the narrative became part of a broader narrative, establishing relationships within the context of a shared geo-cultural market, this affection had a mobilizing effect. The personal and intimate nature of emotions and own affections became part of the shared narrative, presenting the Hispanic world from the perspective of family and community and reinforcing the love-frame as the dominant narrative in this cultural context. Limited initial access to the site meant that international newspapers could at first report only technical details and could not, therefore, interfere with the development of the dominant frame. On the contrary, Western newspapers adopted the love frame and so extended the event beyond the Hispanic world.

\section{Love Frame, Third Stage: Filial, Eros and Cupid}

During this stage, the Chilean and Spanish papers made extensive use of the love frame but also directed media coverage in the rest of the world. Interviewing relatives became compulsory as a method of collecting information from primary sources. Many of the daily reports in the newspapers featured stories that fitted within a frame of filial and romantic love. The concept of filial love has been defined as "affectionate regard or virtue" towards family members (e.g., parents to their children and vice versa), or towards others considered as such (Edwards, 1972). As well as framing stories of this kind, these publications also collected stories involving romance, as these appeared popular among their readers. This shaping can be seen mainly in the Chilean and Spanish papers, both of which chose several filial and romantic love stories and followed them through even after the miners were rescued.

Other examples of the filial love frame included a shared story headlined "Miner meets his new-born baby girl by video message" ( $E l$ Pais, September $15^{\text {th }}, 2010$, International, pp. 14), which also featured in $L U N$ as "Esperanza was born, and she has 32 godparents underground" (LUN, September 15 $5^{\text {th }}, 2010$, p. $3)$. The story appeared in several subsequent reports in both papers over the following days, and a picture in El Pais featured the mother and child, with the caption "Margarita, wife of Ariel Ticona, with baby Esperanza (Hope)." The baby's name alluded to the name of the improvised camp established by the families. References to happiness, joy, and faith were widely used to support the article. $L U N$ developed the story further with details of the birth and the father's reaction, featuring a report on 20 September entitled "Esperanza met her dad in San José mine (by video message)." 
In a shared approach, El País and $L U N$ continued to make regular use of quotes in referring to different romantic love stories. Headlines included similes such as "we are living our honeymoon, let's wait and see what happens [in October]," referring to the time when things would settle and reunions awaited (on the notion of time in media events, see Morgner [2017]). These two papers also developed the narrative regarding the romantic Eros and Cupid love frame, in the manner of a soap opera or reality show (Table 3). Selecting stories such as a love triangle between a miner, his wife, and his mistress, they even involved the Chilean president's wife in the story. She was quoted as saying "I was impressed with the [official] lady; she told me she felt humiliated when her husband (the miner) named them both as emergency contacts" (El País, October $10^{\text {th }}$,
2010, International, p. 1). The newspapers exercised further dramatic license to write detailed accounts of encounters between wives and lovers; $L U N$ dedicated its front cover and a full-page article to this particular love story ("Friends and neighbors tell the love story of the most commented miner on the Internet", $L U N$, October, $15^{\text {th }}, 2010$, pp. 1, 2). In addition, there was a clear geo-cultural connection in $L U N$ 's full-page report on October 22th, entitled "Yonni showed his love to the world on Spanish television," followed by the caption "Antena 3 special programme interviewed the miner and his partner in Chile," presenting a thorough account of the romantic story and the interest of Spanish viewers. These subplots provided an additional element of entertainment within the overall storyline of the mining accident.

Table 3. Love Frame: Third stage

Source: $L U N$

"Miners' partners are getting a makeover to wait for the rescue" (October $8^{\text {th }}, 2010$, p. 7).

“They (miners' partners) are investing in hairdressing, wedding dresses and underwear" (October $8^{\text {th }}$, 2010, p. 7).

"He does not want to be the face of infidelity" (October $22^{\text {nd }}, 2010$, p. 2).

Source: El País

"Some fights among legal wives and lovers in camp Hope" (August 29 $9^{\text {th }}, 2010$, International, p. 3).

"Miner receives letter from partner with marriage proposal $[\ldots]$ he replied: we will talk when I am out" (October 14 ${ }^{\text {th }}, 2010$, International, p. 5).

\section{Source: La Jornada}

"Miner promised partner to buy wedding dress and to get married by the Church" (August $26^{\text {th }}, 2010$, World, p. 22) 
Strong use of the Eros love frame could also be found in the El Pais report of October $15^{\text {th }}, 80$ $\%$ of which detailed romantic stories and insights into the miner's relationships, involving dating, marriage, proposals, renewal of vows, and particulars from primary sources (in this case, the partners).

In comparison to the other two papers, La Jornada deviated less from filial and romantic quotes. Family members were still referred to, although their quotes became much shorter. Analysis of La Jornada during the last stage of the Eros and Cupid love frame showed little reference to romantic stories, with only one small citation (Table 3 ).

\section{Love Frame Differences within the Hispanic World}

The regularity of occurrence of the love frame remained consistent throughout the event, especially in LUN and El Pais, where it appeared often and intensively. La Jornada used the frame slightly less, especially during the last stage. Geographical distance, as well as the fact that natural accidents like earthquakes and landslides often happen without further significance, may well have influenced the initial stages of news coverage. As the Spanish and Mexican papers reported less news information before the miners were found alive, use of the love frame in the first stage was limited in both. Once it became known that the miners were alive, the love frame became prominent in the second stage in all three papers, with intense use of pragma and storge love framing. The main differences can be identified during the last stage, as $L U N$ and $E l$ Pais maintained their consistent use of the romantic love frame while the use of the love frame as a whole diminished in La Jornada and if used at all aligned more with the pragma and storge idea.

Table 4. Love Frame Differences

\begin{tabular}{lll}
\hline \multicolumn{1}{c}{$\boldsymbol{L} \boldsymbol{L U N}$} & \multicolumn{1}{c}{ 2. El País } & \multicolumn{1}{c}{ 3. La Jornada } \\
\hline "Ex-Cobresal player Caqui & Related report not found & "Chilean ex-football player, \\
Lobos trapped in mine for the & & Franklin Lobos Ramirez among \\
second time" (August $7^{\text {th }}, 2010$, & & workers" (August 25 $5^{\text {th } 2010,}$ \\
p. 2) & World, p. 27) \\
\end{tabular}

There were also differences regarding story selection (Table 4). In one example, a miner's daughter described her father's previous survival following a mine collapse and his former life as a nationally known footballer.
She was quoted as saying "my father is very resilient. He will come out. This is the most important 'match' of his life, and he will win it [...] I won't give up hope that [they] will be saved" (LUN, August $8^{\text {th }}, 2010$, p. 4). The quote 
was followed by a statement about the strength of family unity and how the football match metaphor relates to the challenges miners face. The reason for this story's inclusion may be that football plays an important role in Chilean society. The sport is followed and played formally or informally by most of the population (Informe de Prensa, 2010) and occupies most of the sports pages in most Chilean newspapers. This story also appeared in La Jornada. On August $25^{\text {th }}$, a caption under the main headline declared "Ex footballer is one of 33 trapped in mine," with a photograph of the miner in question. The report used language and a common lexicon similar to the Chilean paper and again emphasized the miner's sporting background. Selected quotes had an element of humor; "we wanted to send you a football, but it does not fit in the tube" was attributed to the miner's daughter (La Jornada, August $25^{\text {th }}$, 2010, p. 2). In Mexican society, football is also the preferred sport, as indicated by the same paper's sports section. This small story did not receive the same attention in El País, where no reference could be found. Although the Spanish community follows football very carefully, the love frame was developed differently in this paper, as explained in the previous analysis. Although the love frame played a dominant role in the overall framing and narrative, this confirms the absence of homogenous geocultural media coverage. While geo-cultural markets can transcend regional differences and reinforce frames, they are also liable to localize these frames, so embedding them in subcultural markets at national, local and individual levels.

\section{Extension of the Event: Building and Interlinking of New Frames}

The third stage shows signs of exhausting the love frame. However, its decline did not lead to any sudden death of the media event. By that time, the event had gained considerable media attention, interrupting the daily flow of news and acquiring weight of its own (Dayan \& Katz, 1992). The event was on! Other research in this field has pointed to the network-like quality of events emerging from such conditions (Morgner, 2016) as the importance of the event may be extended and explored in other areas, leading to the development of new frames. In this regard, we will look in particular at the 'heroes frame,' with some brief remarks in conclusion about a few other frames.

\section{Construction of the Heroes Frame}

The rise and decline of the love-frame opened up new narrative possibilities. The research identified two other frames: Hi-Tech frame and Hero Frame. The study showed that a 'Hi-Tech frame' was driven a by a more factual narrative, which was very similar across the three newspapers including noticeable features like technical acronyms, jargon specific to the mining industry, slangs, metaphors, and similes. Across almost 70 days of reporting, the publications provided generally standardized amounts of pictures, stories, quotations, and references, making the 'Hi-Tech framing' a very unswerving frame within the Hispanic geo-cultural market that seemed to rely on existing journalistic practices that employ such 
factual narratives. The present research paper, therefore, seeks to demonstrate the establishment of a shared 'construction of heroes' frame, whose creation and legitimation in the media relied on a connection with its geocultural market. Whereas the love frame established a connection through its personal dimension and the Hi-Tech frame could rely on the existing journalistic practice of factual reporting, we will argue that the heroes frame transcended national boundaries through its links with the iconic image of the politicized hero in the Hispanic world.

In contemporary society, the media often refers to 'modern-day heroes,' often related to personal achievements or the universal admiration of others in the face of adversity. In the case of the Chilean mining accident, the media used the heroism concept to frame the narrative, building on the idea of ordinary workers as heroic figures, overcoming reduced chances of survival, facing imminent death and emerging as symbols of national pride and international admiration. The analysis revealed that a 'construction of heroes' frame appeared within days of the 33 miners' signs of life and then developed steadily until they were rescued. Across all three papers, the frame itself was equivalent in structure, use of language and quotes. However, the 'construction of heroes' frame was more readily identifiable in $L U N$ and El Pais, in three recognizable phases: initial, developmental and concluding. In La Jornada, the frame was less in evidence during the developmental phase.

\section{Primary phase: Towards building heroic protagonists}

Heroic figures can be found in every society, past to present, from fictional tales to factual historical accounts. So how does an ordinary human being attain such status, and what constitutes a hero? The concept presents several possibilities; a hero for one may not be so for another. Traditional definitions conceptualize the hero as '[someone] who becomes admired for his or her courage, outstanding achievements, and noble qualities' (Simpson, 2016). Historically, a hero has been thought of as someone who has done something extraordinary or unexpected, overcoming the unthinkable and inspiring peers to follow their exemplary behavior (Hook, 1955). For instance, Grinin (2010) stated that a heroic figure could be identified by a selection of attributes of an individual or individuals within or around specific situations, such as leadership, performance, personality, and emotions. Heroes stand out from the rest, in the sense that others may be incapable of reacting in the same way under similar conditions. Peers may feel emotionally connected and seek to idolize their heroes, rewarding them with respect, using them as references and seeking to be associated with them. The meaning and representation of the hero has continued to evolve and may vary between cultures and societies (Goethals \& Allison, 2012). In this case, the miners have become heroes mainly because they overcame tragedy and survived a calamity, linking them to existing models of the politicized hero in the Hispanic world (Brunk \& Fallaw, 2006). 
Table 5. Constructions of Heroes: Primary phase

\begin{tabular}{l|l}
\hline \multicolumn{1}{c|}{$\boldsymbol{L} \boldsymbol{L} \boldsymbol{U} \boldsymbol{N}$} & \multicolumn{1}{c}{ El País } \\
\hline "What could be in the mind of the 33 miners? & "Losing hope: we don't want a tomb" (August \\
$\begin{array}{l}{[\ldots] \text { facing the tragedy, the first reaction is of }} \\
\text { horror" (August } 10^{\text {th }}, 2010, \text { p. 3) }\end{array}$ & 2010 , Headline International, p. 1) \\
"rescue plans overshadowed by thumping rock in & "Could there be any super-survivors?" (August \\
the disaster zone" (August $16^{\text {th }}, 2010$, p. 22) & $21^{\text {st }}, 2010$, International, p. 2) \\
\hline
\end{tabular}

In the first instance, our analysis indicated that the media's selection of language denoted the fatal consequences of the accident and the improbability of finding the men alive. Words such as, buried, trapped, tragedy, survivors, horror, risk, fail and tombs, were used in the Chilean and Spanish papers. As the paper with most immediate access, $L U N$ broadcast the idea of a potentially fatal outcome and built on this until the news broke that the 33 men were found sheltering. El Pais appears to have fed on the Chilean paper, developing a similar lexicon and narrative (see Table 5). Communications to and from the men were monitored by the Chilean government and the national press ( $L U N$, October $12^{\text {th }}, 2010$, p. 8 ), and this frame seems to have carried from national to international news providers (Jiménez-Martínez, 2010). The front page of $L U N$ 's special edition of August $23^{\text {rd }}, 2010$ stated "More alive than ever," above a frontal close-up of one of the men from inside the mine. On the next page, the main headline read "Heroes do exist" (Figure 3).

Figure 3. Constructions of Heroes: Primary Phase
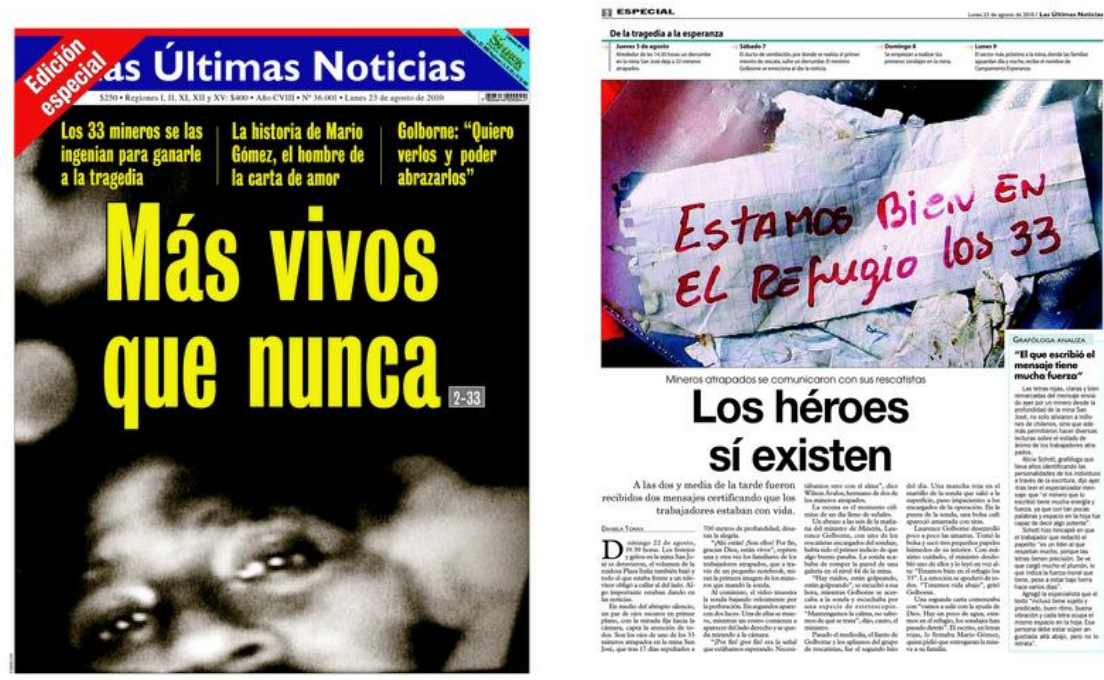

Source: $L U N$, August $23^{\text {rd }}, 2010$, p. 1-2. 
Sentence choice here was simple but particularly strong, as the word 'hero' in itself conveys a concept of wider significance, as discussed earlier. The paper included a picture of a handwritten note (which in itself became an iconic item) written by one of the miners to confirm their safety: "We are well in the shelter, the 33." (Figure 3). This was not the only note recovered at the time, but the fact that it was short, printed in red ink and had a simple and solid message made it the ideal symbol of heroic action. On the same date, El País headlined its international section "Traced alive: the 33 miners buried for 17 days in Chile." (El País, August 23 $\left.{ }^{\text {rd }}, 2010\right)$ It also mentioned the recovered note, as if the men had been sending signals from the great beyond, as well as referring to bravery and courage. The selected language from these quotes dispelled any conception of the miners as ordinary people, presenting them instead as a group that had achieved something that others might not (Table 6).

\section{Table 6. Constructions of Heroes: Primary Phase}

\section{Source: $L U N$}

"33 miners' ingenuity to win over tragedy" (August $23^{\text {rd }}, 2010$, Cover p. 1)

"Miners sent message certifying they are alive" (August $23^{\text {rd }}, 2010$, Cover p. 1)

Source: El País

"written in strong red letters: we are well in the shelter the 33"; "at 700 meters underground, miners are unhurt" (August 23 $3^{\text {rd }}, 2010$, International, p. 1)

Source: La Jornada

"Miners surprised the world after sending life signals" (August 24 ${ }^{\text {th }}, 2010$, World, p. 40)

In another characteristic move in the primary stages of building heroic characters, the papers developed a narrative concerning the conditions under which ordinary workers had managed to survive the mine collapse. As it is widely known that working in a mine carries risks, it can be assumed that if this event had led to casualties or deaths, the news coverage would have been quite different. However, once the miners were found safe, the media classified them as survivors of a catastrophe and began to build on this idea. In doing so, the three publications referred to survival strategies, leadership, and organization. Examples in $L U N$ highlighting organized and strategic work referred to "surviving [eating] two spoons of tuna every 48 hours" (LUN, August $24^{\text {th }}, 2010$, p. 3). El País consolidated this approach: "in temperatures of 35 degrees and $98 \%$ humidity, miners collected water from the shelter's roof" (El País, August $23^{\text {rd }}, 2010$, International, p. 2). Both papers adopted this narrative to offer lengthy explanations of the men's efforts. Although La Jornada echoed this approach, 
references to this frame were less prominent and did not necessarily appear in headlines or captions. On August $24^{\text {th }}$, however, they included a quote similar to that in $L U N$ : “...surviving thanks to two spoons of tuna and a half glass of milk-every 48 hours" ( $L a$ Jornada, August $24^{\text {th }}, 2010$, Mundo, p. 41).

\section{Secondary Phase: Developing Roles and} Personas

It might be disputed that newspapers use the word 'hero' and 'heroic' regularly and in different scenarios. Arguably, there is no way of measuring how heroism is seen by an audience; is it the act itself, its impact on others or its consequences that afford such status? This may be a subjective matter. According to Johns, "Heroism has always been a powerful concept. [...] Heroic virtues could be cultivated [...], heroic actions come from traits of character that most men (with the right input) have the potential to develop: the exercise of reason, standards of morality and admirable selfdiscipline." (1991, p. 4)

When dealing with events such as disasters, media broadcasters may seek to present a unified perception of a hero or heroic model as a means of reaching the wider population. It appears that standard characteristics may be used to assign individuals to a heroic role, including bravery, charisma, leadership (including decision making, tenacity and skill), altruism, compassion, visionary ideas, moral beliefs or principles, integrity, honesty, and fairness. In this second phase, the three selected newspapers shared elements of a perspective on heroic figures but began to present those features in a politicized way. Identifying a few leaders and organizers from the miners' group, exemplary references were found repeatedly and with similar frequency in the Spanish and Chilean publications, with briefer references in the Mexican paper, where the reports were generally shorter.

Apart from the use of descriptive language, profile-style statements and pictures of the chosen individuals were also featured. $L U N$ and El Pais showed this content as small bibliographic-style reports of selected miners, with supporting quotes from relatives about their personality and likely emotional state. For instance, on August $26^{\text {th }}$, LUN dedicated a whole page to a detailed account of the leading miners (Figure 4).

\section{Figure 4. Secondary phase: Developing roles and personas}

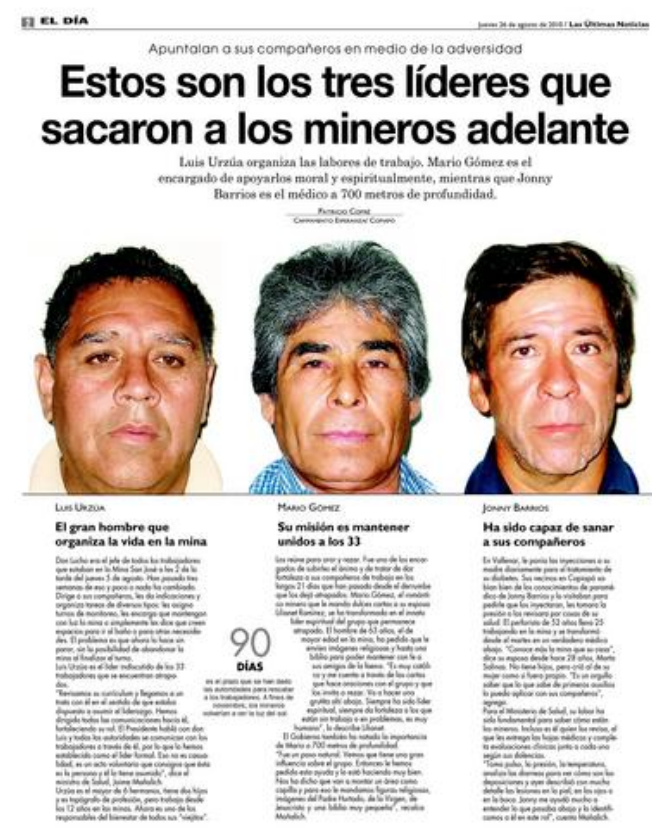

Source: LUN, August, $26^{\text {th }}, 2010$. 
El Pais chose to write about eight of the miners, giving them nicknames appropriate to their assigned roles: the veteran, the journalist, the comedian, the sportsman, the nurse ("capable of healing his comrades") (LUN, August $26^{\text {th }}$, 2010, p. 2) and the spiritual guide ("who has helped us all immensely") (El País, August $28^{\text {th }}, 2010$, International). In assigning these roles, the papers used a lexicon familiar to the rest of the population, with generally positive connotations. The use of nicknames and sobriquets to describe the miners was found throughout the 'construction of heroes' frame in El País and LUN but not in La Jornada.
The lengthy journey towards rescue may also have supported the development of the second phase of this frame, as it afforded the media scope to dig deeper into the lives and personae of the chosen miners. As communication with the miners became more frequent, thanks to the possibility of video recording and exchanges of letters, more could be learned and reported about the miners' characters and personalities. Their positive qualities and disposition appealed to the audience and generated a closeness with the men (Table 7), who had managed to resist despair in spite of the extreme conditions.

\section{Table 7: Constructions of Heroes: Secondary Phase}

Source: $L U N$

"Miner who wrote the note must be very strong and energetic, in just a few words he was able to send such a powerful message" (August $23^{\text {rd }}, 2010$, p. 2)

"We knew Mario was helping, that is just his spirit and temper" (August $23^{\text {rd }}, 2010$, p. 3)

'The poet, Victor Zamora, sends poetic writings to the surface in a wet paper" (September $4^{\text {th }}, 2010$, p. 4)

"Luis is a great son and person [...] he had to assume a lot of responsibility since very young" (October 14 $4^{\text {th }}, 2010$, p. 2)

\section{Source: El País}

"I admire the sense of humour of Sepulveda, $[\ldots]$ as he installed the video system among the rubble and debris" (October $9^{\text {th }}, 2010$, International)

"Luis is a very special person; without his collaboration, a different story would be told" (October $10^{\text {th }}, 2010$, International, p. 4)

"Urzúa was the key man in maintaining discipline and harmony during the time they were incommunicado" (October 10 $0^{\text {th }}, 2010$, International, p. 4)

\section{Source: La Jornada}

"Although miners expect a long wait until their rescue, they are calm and high-spirited "(October $10^{\text {th }}, 2010$, World, p. 25)

The argument here is not about whether or not the men had valuable ethical qualities but how the media exaggerates their usage to keep audiences interested. This can be a difficult 
task, and reporting on the same event over a period of time needs to be captivating. In journalistic practice, proximity, familiarity, timing, and locality are well-established criteria for audience engagement (Graber, 2009). The papers acted as 'gatekeepers' (Shoemaker \& Vos, 2009), feeding readers a continuous stream of insightful stories to develop the relationship with the men, sharing their experiences at a more intimate level. In the Hispanic geo-cultural market in question, this 'construction of heroes' frame was shaped in the second phase by creating an acquaintance between miners and the public. This was more pronounced in the Chilean and Spanish newspapers and occurred to a lesser extent in La Jornada.

\section{Final Phase: Heroes are Born}

As the rescue day drew closer and the operation took effect, the 'construction of heroes frame' took root in the three newspapers. From being ordinary men, the 33 were about to be reborn from the center of the earth as heroes. As previously discussed, heroes are part of social creation. Dermenjian, Guilhaumou, and Lapied (2004) elaborate that a hero's story is told and changes throughout time, it serves different purposes of memory and propaganda with a view into diverse social, political or religious evolutions. Within the Hispanic geo-cultural market, politicized heroic icons seem important in various ways. Here, we use the word politicized in a broader sense to refer to the power struggles and collective decision-making processes that transpire outside government power structures (see Beck, 2008). Chile, Spain, and Mexico share a cultural background, and throughout their history, a series of socalled 'heroic' characters have informed the making of their imaginary communities, including Father Hurtado, Pelé, Simón Bolívar, Emiliano Zapata and Evita Perón. Unsurprisingly, then, the media drew on this construction in the event of this disaster; regular workers, to whom many could relate, made a nation proud by staying alive under harsh conditions. The already developed resonance of imminent rescue was fresh in the public mind and was about to reach its climax.

Consolidation of the frame could be seen in all three publications, shaping their reports within the same narrative. People received the miners as heroes, but in the final stages, this developed within a strongly politicized context that compared them to existing icons. Equivalent language features could be found between the newspapers, beginning with $L U N$, which employed qualifying adjectives such as great, greatest, admirable, delight and super to consolidate the miners' personas.

Further examples emerged in $L U N$ 's 24-page special edition, named Fenix, as a metaphoric reference to the 'rebirth' of the 33 . Simply but boldly, its cover page read "Super Mario," above a photograph of a euphoric miner exiting the mine. The paper went on to supply detailed fact file-style information on each of the miners - now heroes - on several dedicated pages, calling them "Chile's most courageous" (LUN, October $13^{\text {th }}, 2010$, pp. 114). Central to each report were quotes gathered 
directly from the protagonists, as reporters gained access to the men soon after their rescue. In shaping this 'heroes are born' phase, the chosen quotes seemed to invoke a level of patriotic clichés: "I'm a miner at heart; it's in my blood," (as reportedly said by Alex Vega) or "Victor Zamora: more than co-workers, now
I have brothers." (LUN, October $15^{\text {th }}, 2010, \mathrm{p}$.

6) There were also many references to people celebrating in the streets, singing the national anthem, waving flags and chanting allocutions, almost as if the men had returned victorious from an epic battle.

Table 8. Constructions of Heroes: Final phase

\section{Source: El Pais}

“Long live (Hurray) Chile, long live (Hurray) the miners!” (August 28 ${ }^{\text {th }}, 2010$, International, p. 1)

"Trapped miners close to their 'D-Day"” (October $8^{\text {th }}, 2010$, International, p. 4)

“[...] Chilean miners are symbols of national pride" (October $12^{\text {th }}, 2010$, International, p. 2)

“[...] the only truth: 33 men escaped death (October $14^{\text {th }}, 2010$, International, p. 8)

"Inside the mine, a flag was left with a2 message: mission accomplished" (October $14^{\text {th }}, 2010$, International, p. 2)

\section{Source: La Jornada}

“[...] miners close to completing their feat" (October 12 $2^{\text {th }}, 2010$, World, p. 29)

“[...] euphoric welcome to miners throughout epic journey" (October $13^{\text {th }}, 2010$, Politics, p. 5)

"Amid clapping, cheering and the singing of the national anthem (the miners were received)" (October 13 ${ }^{\text {th }}, 2010$, Politics, p. 5)

"Fantastic! Miners' feat was watched by thousands of millions" (October $13^{\text {th }}, 2010$, Front cover)

Both El País and La Jornada settled on a miners-heroes-patriots narrative, as in “Trapped Chilean miners close to their ' $D$ Day"' (El País, October $8^{\text {th }}, 2010$, International, p. 4). Comparing the miners' rescue ordeal to an event such as D-day, known for its historical and global repercussions, immersed the audience in a patriotic ideal, in which the 33 men were perceived primarily as symbolic soldiers and returning heroes. La Jornada adopted the same approach, portraying the miners as emblems of pride; in its edition of October $13^{\text {th }}$, coverage of the miners occupied the front page. "Fantastic!" was the headline above a photograph of the first worker to reach the surface. Subsequent captions made references to the "epic journey the men had to endure" (La Jornada, October 13 ${ }^{\text {th }}, 2010$, pp. 16). As shown in Table 8, words like epic, mission, nation, pride and feat and phrases such as long live or hurray prompted the audience to perceive the event in a particular way. During 
phase two of the frame, the media developed a representation of the miners; now, in the final phase, they were consolidated as the people's symbolic figures. With this construction of heroes framing, the media also managed to engender a homogenous concept of hero that was ultimately shared within the Hispanic geocultural market.

\section{Differences in the Construction of Heroes Frame}

On reviewing the construction of heroes' frame, the framing was found to comprise initial, developmental and concluding phases. In a significant difference during the second phase, La Jornada seemed to have skipped the roles and personas phase to accommodate other frames or indeed altogether different news items. However, the phases were in general well demarcated across the newspapers and throughout coverage of the event. Only a few additional stories could be identified, indicating different perspectives between the three countries in the selected geo-cultural market.

To sustain the 'hero' narrative, $L U N$ went on to deliver a series of additional supporting articles, including praise and acclaim from the social media community via portals such as Facebook or Twitter. Local and international celebrities contributed, reinforcing the idea that the miners' ordeal and survival transcended local boundaries and projected their status as heroic and worthwhile individuals. Although these stories were not discussed in La Jornada or El País, La Jornada commented briefly on the miners' record of survival underground, echoing what the Chilean paper had reported on a couple of occasions.

On the other hand, El País featured a story that did not appear in LUN or La Jornada. Its headline on October $10^{\text {th }}$ read 'The day in which the miners defied their leader,' followed by the subheading "The rebellion against the boss [...] kept secret" (El Pais, October 10 ${ }^{\text {th }}$, 2010, International, p. 2). The following day, a reprint was issued. It might be argued that as an external provider, El País favored news items that included an element of drama and sensationalism to entertain their audience. As a Chilean national paper, $L U N$ might have deemed this story controversial, as it implied defiance of the leadership role of one miner. However, this did not jeopardize the explicit construction of iconic figures within the frame in the Spanish publication, instead supporting the perceived importance of the politicized hero.

\section{Media Events and Geo-Cultural Markets}

This research has explored media coverage of the 2010 Chilean mining disaster from the perspective of geo-cultural markets. Limiting the scope of this paper to two mainframes, their interrelation and their role in the Hispanic world, we considered their impact on media coverage of the event. As noted earlier, these were not the only frames in play; other strong frames included: 'Hi-Tech frame', dealing with the technological and mechanical aspects of the 
miners' rescue; the 'Politicians as Celebrities' frame, relating to the portrayal and public perceptions of public figures during the event; the 'Life Under' frame, involving regular descriptions of the facilities, resources deployed and the conditions experienced by the miners throughout their time underground; the 'Morals and Responsibility' frame, concerning the communities' search for answers, accountability and closure and their relationship with mundane and divine beliefs. Other cultural aspects of the Hispanic geocultural market were highlighted, including the roles of men and women, depictions of femininity and masculinity and sexism. The analysis also addressed the possibility that some of the frames could be said to have positive or negative connotations, suggesting that more research is needed to deliver a more traditional media frame analysis. Here, the identification of frames related to the dynamic of media events and their embedding in a geo-cultural market. In this context, three interrelated questions addressed the framing of this event within a geo-cultural market, raising the question of how this accident became a media event.

We believe that the concept of geocultural markets provides an appropriate theoretical background to guide our empirical research and formulate relevant answers. The transformation of the accident into a media event was based on the introduction of the "love frame.' While this frame was initially a very local set-up and therefore attracted only media from Chile, it was soon reinforced and supported through embedding in a world of shared feelings, personal relationships and intimacy, based on a cultural reading of the event that constructed the Hispanic world as a family or community. The love-frame simulated a connection or dialogue through which people could relate to the event, imagining a brother, son, husband or father in a similar situation. Beyond being a context to which the media coverage could be extended, the geo-cultural market was itself a feature in the formation of the media event, as the transnational and transcultural dimension became part of the narrative. However, the findings suggest that this transnational dimension cannot be grasped simply in terms of homogeneity or repetition. The framework was open both to localization and to presenting emotions in a more national or regional context.

This function of the geo-cultural market was also evident in the other important frame of the event: the heroes frame. The miners were not heroes in the sense of having some superpower; instead, they were associated with iconic images in the history of the Hispanic world, as ordinary men who can overcome the challenges of their immediate environment to become larger than life figures. This politicized reading presented the miners as being above cultural differences, symbolizing a cultural interpretation that transcends cultural borders because, according to the media coverage, it is shared by all people across the Hispanic world. This function of the geocultural market as a source of internationalization is often overlooked in research on media flows. Media flows are often analyzed from the perspective of the world 
system dividing the world into center and periphery and thereby disregarding such transnational flows (see Chang, 1998).

The results of this analysis also indicate that, during the early stages, most of the frames deployed originate in the vicinity of an event rather than from external broadcasters. As compared to the development of framing material in Mexico and Spain, it was clear that the initial frames from Chile sought to portray a specific view of the event that was then acknowledged by the other countries, with some adjustments to suit their target audiences. This finding has implications for further research on the socio-historical construction of geo-cultural markets through transnational media events of this kind. The semantics of the Latin-American and Hispanic World cannot merely be seen to have evolved in almost natural fashion through mere proximity and similar languages. Instead, the formation of such imaginary communities relates much more to their constructions of meaning (Anderson, 1991). Research on the rise of nation-states has acknowledged the importance of the media as a critical element in such imagined communities (see Madianou, 2005); we would now add that such transnational events may influence the formation of geo-cultural markets. This suggests that further research might usefully address other events that have attracted similarly intense media coverage in this region-for instance, the opening of the Panama Canal or the Cuban missile crisis.

Another significant finding is that systematic and combined use of the frames was needed to sustain audience interest. Across the coverage of this event, La Jornada, El País and $L U N$ were seen to deploy the identified frames in their reports regularly. The analysis further confirmed that the frames identified in the three publications largely reflected shared cultural factors across the three nations. Most of the language, style, and content of news items suggested that the frames were to some extent equivalent. This makes sense as an indication that geo-cultural markets are firmly grounded in identifiable elements and contexts that connect individual nations.

\section{References}

Anderson, B. R. (1991). Imagined communities: Reflections on the origin and spread of nationalism (Revised and extended. ed.). London: Verso.

Beck, U. (2008). Reframing power in the globalized world. Organization Studies, 29(5), 793-804.

Brewer, P. R., Graf, J., and Willnat, L. (2003). Priming or framing media influence on attitudes toward foreign countries. International Communication Gazette, 65(6), 493-508.

Brunk, S. and Fallaw, B. (2006). Heroes and hero cults in Latin America. Austin: University of Texas Press.

Bullock, H. E., Wyche, K. F., and Williams, W. R. (2001). Media images of the poor. Journal of Social Issues, 57(2), 229-246. 
Chang, T.-K. (1998). All Countries Not Created Equal to Be News: World System and International Communication. Communication Research, 25(5), 528-563.

D’Angelo, P., and Kuypers, J. A. (2010) (Eds.). Doing News Framing Analysis. London: Routledge.

Dayan, D., and Katz, E. (1992). Media events: The live broadcasting of history. Cambridge, MA: Harvard University Press.

Dermenjian, G.; Guilhaumou, J., and Lapied, M. (2004). Le panthéon des femmes: figures et représentations des héroines. Paris: Éd. Publisud.

Edwards, P. (1972). The Encyclopedia of Philosophy, Volumes 5-6. Macmillan \& Free Press.

Entman R. M. (1993). Framing: Toward Clarification of a Fractured Paradigm. Journal of Communication, 43(4), 51-58.

Entman, R. M. (1991). Framing U.S. coverage of international news: Contrasts in the narratives of the KAL and Iran Air incidents. Journal of Communication, 41(4), 6-27.

Fox, A. (2016). Global Perspectives on Media events in Contemporary Society. IGI Global.

Goethals, G. R., and Allison, S. (2012). Making heroes: The construction of courage, competence and virtue. In M. P. Zanna \& J. M. Olson (Eds.), Advances in Experimental Social Psychology (pp. 183-231). London: Academic Press.

Goffman, E. (1974). Frame analysis: An essay on the organization of experience. Boston: Northeastern University Press.

Graber, D. (2009). Mass Media and American Politics. Washington, DC: CQ.

Grinin, L. (2010). The role of an individual in history: A reconsideration. Social Evolution and History, 9, 95-108.

Hansen, A. and Machin, D. (2018). Media and Communication Research Methods, $2^{\text {nd }}$ edition. London: Macmillan International Higher Education.

Hoiberg, D. (2010). The Encyclopaedia Britannica: 15th edition. A dictionary of arts, sciences and general literature (Vol. 10, 1985-2010). London: Werner.

Hook, S. (1955). The hero in history: A study in limitation and possibility. Boston, MA: Beacon Press. Hooper, W. (2005). C. S. Lewis: A companion and guide. London: HarperCollins Entertainment. Informe de Prensa. (2010). Estudio Nacional de Fútbol. Providencia, Santiago: Corporación CERC. Iyengar, S., and Simon, A. (1993). News coverage of the Gulf crisis and public opinion. A study of agenda-setting, priming, and framing. Communication Research, 20(3), 365-383.

Janssen, M. C. (2010). A framing analysis of weblogs and online newspapers. San Jose State University: SJSU Scholar Works.

Jiménez-Martínez, C. (2014). Disasters as media events: The rescue of the Chilean miners in national and global television. International Journal of Communication, 8, 1807-1830.

Johns, E. (1991). Thomas Eakins: The heroism of modern life. Chichester, UK: Princeton University Press. 
Krznaric, R. (2014). How should we live? Great ideas from the past for everyday life. Los Angeles: Blue Bridge Publications.

Levin, I. P., Schneider, S. L., and Gaeth, G. J. (1998). All frames are not created equal: A typology and critical analysis of framing effects. Organizational Behavior and Human Decision Processes, 76(2), 149-188.

Liddell, H. G., and Scott, R. (2010). An intermediate Greek-English lexicon: Founded upon the seventh edition of Liddell and Scott's Greek-English lexicon. Benediction Classics.

Lozano, J., Abril, G., and Peña-Marín, C. (2004). Análisis del discurso. Madrid: Cátedra.

Lozano, J., Peña-Marín, C., and Abril, G. (1993). Análisis del discurso. Hacia una semiótica de la interacción textual. Madrid: Cátedra.

Madianou, M. (2005). Mediating the nation: News, audiences and the politics of identity. London: UCL Press.

Martinovsky, B. (2010). Cognitive and emotive empathy in discourse: Towards an integrated theory of mind. Marina del Rey, CA: Institute for Creative Technologies, University of Southern California. Retrieved from http://ict.usc.edu/pubs/Cognitive\%20and\%20Emotive\%20Empathy\%20in\%20Discourse\%20Towards\%20an\%20Integrated\%20Theory\%20of\%20Mind.pdf

Morgner, C. (2016). Global Media Events: Kennedy, Titanic, Fukushima. In A. Fox (Ed.), Global Perspectives on Media Events in Contemporary Society (pp. 1-16). IGI Global.

Morgner, C. (2017). Global Media and Time. Studies in Communication Sciences, 17(1), 57-76.

Nelson, T. E., Clawson, R. A., and Oxley, Z.M. (1997). Media Framing of a Civil Liberties Conflict and Its Effect on Tolerance. The American Political Science Review, 91(3), 567-583.

Ong, W. J. (2002). Technological development and writer-subject-reader immediacies. In author, $A n$ Ong reader: Challenges for further inquiry (pp. 497-504). Cresskill, NJ: Hampton Press Inc.

Perry, R. W. (2007). What Is a Disaster? In H. Rodríguez, E. L. Quarantelli, \& R. R. Dynes (Eds.), Handbook of Disaster Research (pp. 1-15). New York: Springer.

Reese, S. D., Gandy, O. H., and Grant, A. E. (2008). Framing public life: Perspectives on media and our understanding of the social world. In A. Hansen (Ed). Mass communication research methods. Los Angeles: Sage.

Schultz, F., Kleinnijenhuis, J., Oegema, D., Utz, S., and Van Atteveldt, W. (2012). Strategic framing in the BP crisis: A semantic network analysis of associative frames. Public Relations Review, 38(1), 97-107.

Shoemaker P. J., and Vos, T. P. (2009). Gatekeeping Theory. New York: Routledge.

Simpson, J. (2016). Oxford English Dictionary Online. Oxford: Oxford University Press. Retrieved from http://www.oxforddictionaries.com/definition/english/hero

Straubhaar, J. D. (1991). Beyond Media Imperialism: Asymmetrical interdependence and cultural proximity. Critical Studies in Mass Communication, 8, 1-11. 
Straubhaar, J. D. (1997). Distinguishing the global, regional and national levels of world television. In A. Sreberny Mohammadi, D. Winseck, J. McKenna, \& O. Boyd-Barrett (Eds.), Media in global context: A reader (pp. 284-298). London: Edward Arnold.

Straubhaar, J. D. (2007). World television: From global to local. Los Angeles: Sage.

Van Gorp, B. (2007). The constructionist approach to framing: Bringing culture back in. Journal of Communication, 57(1), 60-78. 